\title{
Response predictors to treatment with pegylated interferon in chronic hepatitis B
}

\section{ABSTRACT}

The clinical and epidemiological importance of chronic B hepatitis is currently unquestionable as a cause of end-stage liver disease and hepatocellular carcinoma. Recently, predictors of treatment response of this disease have been studied, both before and during the course of medication. Therapy stopping rules have been proposed, which may be useful in patients presenting poor treatment tolerance. This review discusses the treatment response predictors usefulness, with emphasis on ALT, quantitative $\mathrm{HBsAg}$ and $\mathrm{HBeAg}$, quantitative HBV-DNA and HBV genotype.

Keywords: hepatitis B, HBsAg, HBeAg, HBV-DNA, pegylated interferon.

[Braz J Infect Dis 2010;14(5):519-525]@Elsevier Editora Ltda.
Authors

Paulo Roberto Abrão

Ferreira $^{1}$

Simone de Barros Tenore

${ }^{1}$ Physician of the HIV and Viral Hepatitis Outpatient Clinic of the Discipline of Infectious Diseases of UNIFESP; Member of the Viral Hepatitis Group of CRT STD-Aids in São Paulo - Brazil.

${ }^{2}$ Master's Degree in Infectology by UNIFESP; Assisting Physician at HIV and Hepatitis Outpatient Clinic at UNIFESP; Physician of the Viral Hepatitis Group at CRT DST-Aids in São Paulo Brazil.

\section{Long-term evolution markers}

Infection by hepatitis B virus (HBV) is a global health problem, which currently affects around 400 million people worldwide. It is estimated that more than 200,000 to 300,000 patients with chronic hepatitis B die annually due to liver cirrhosis and hepatocellular carcinoma, respectively. ${ }^{1}$ Persistent viral replication is associated with disease progression. As a consequence, antiviral therapy must achieve maximal suppression to improve the clinical outcome. As no antiviral treatment is perfect, it is advantageous to evaluate response prediction factors to modify the therapeutic regimen according to these indications. ${ }^{2}$

As liver complications occur over decades, most therapeutic studies use shortterm surrogate response markers. To evaluate predictors of treatment response, one must understand the meaning and the importance of each of these markers. Moreover, the response during treatment with nucleotide analogs (NA) must be clearly differentiated from the response achieved after treatment with pegylated interferon (PEG-IFN).

\section{Elimination of the hepatitis B surface antigen (HBsAg)}

Elimination of HBsAg, with or without the development of anti-HBs antibody, is considered the criterion for HBV infection resolution and, probably, the best definition for virological response. ${ }^{3-5}$ Longitudinal studies have demonstrated that HBsAg serological disappearance represents an excellent long-term prognosis, given that the loss of HBsAg occurs in younger individuals ( $<50$ years) and prevents the development of advanced fibrosis and cirrhosis. ${ }^{6}$ Unfortunately, it seldom occurs, either spontaneously or after antiviral treatment. In general, HBsAg disappearance is a sustained event, except when the patient becomes immunosuppressed. However, a German study demonstrated that HBsAg can reappear after treatment discontinuation with pegylated interferon, in spite of the maintenance of treatment with adefovir. ${ }^{7}$
Submitted on: 08/14/2010 Approved on: 09/02/2010

Correspondence to:

Paulo Roberto Abrão Ferreira

Rua Ouvidor Peleja, 235, ap 101

Vila Mariana - São Paulo

- SP - Brazil

CEP: 04128000

E-mail: paulo.abrao

ferreira@gmail.com

The corresponding author participates in the Hepatitis Scientific Committees of SBI, MSD and ROCHE; Principal Investigator in clinical trials sponsored by MSD, ROCHE, BMS, and Janssen; MSD, and ROCHE lecturer. 


\section{Seroconversion of antigen e of hepatitis B virus ( $\mathrm{HBeAg}$ )}

In HBeAg-positive patients with chronic hepatitis B, disappearance of $\mathrm{HBeAg}$ and seroconversion for anti$\mathrm{HBe}$ is usually considered a satisfactory outcome during antiviral treatment. ${ }^{3-5}$ Disappearance of $\mathrm{HBeAg}$, whether spontaneous or post-antiviral treatment, reduces the risk of hepatic impairment and increases survival. ${ }^{8-11}$ Nevertheless, $10 \%-30 \%$ of the patients can still present high ALT and high levels of HBV-DNA after HBeAg seroconversion and $10 \%-20 \%$ of the inactive carriers may reactivate HBV replication and have exacerbation of hepatitis after years of quiescence. ${ }^{12-14}$ Most hepatitis flares, after $\mathrm{HBeAg}$ seroconversion occur within six months after interferon therapy withdrawal, but can occur later, and even a few years after lamivudine withdrawal. ${ }^{15,16}$ As a consequence, seroconversion of HBeAg can be used as a response marker only when sustained for at least six months after the end of therapy, and may be the best marker for treatment with pegylated interferon compared to NA.

\section{Viral suppression of $H B V-D N A$}

Many Asian prospective studies have demonstrated that a high level of HBV-DNA was an independent risk factor for the development of cirrhosis and hepatocellular carcinoma. ${ }^{17,18}$ Therefore, persistent suppression of the HBV-DNA, ideally at an undetectable level or, at least, at a level of $2,000 \mathrm{UI} / \mathrm{mL}(10,000$ copies $/ \mathrm{mL})$, is another acceptable marker for treatment response. In studies that analyzed treatment with lamivudine in $\mathrm{HBeAg}$ negative patients or those with advanced liver fibrosis, sustained viral suppression was associated with the decrease in complications of cirrhosis and hepatocellular carcinoma. ${ }^{11,19,20} \mathrm{~A}$ recent meta-analysis showed that the risk of hepatocellular carcinoma can be significantly decreased with viral suppression through antiviral therapy. ${ }^{21}$ After NA withdrawal, relapse of viral infection can occur in most $\mathrm{HBeAg}$-positive individuals that did not loose the $\mathrm{HBeAg}$, as well as in $\mathrm{HBeAg}$-negative individuals. The durability of drug induced viral suppression after a one-year treatment with lamivudine or adefovir in HBeAg patients has been $<10 \% .{ }^{3,23}$ For HBeAg-negative patients that receive peginterferon, most who maintains HBV-DNA suppression $<2,000 \mathrm{UI} / \mathrm{mL}$ for one year after treatment, will sustain viral suppression up to the third year. ${ }^{24}$ Consequently, the use of HBV-DNA levels as a surrogate marker for treatment response is valid only if viral suppression is maintained during NA treatment. As for treatment with peginterferon of $\mathrm{HBeAg}$-negative patients, the sustained suppression of the HBV-DNA up to one year after treatment is also a reasonable response marker.

\section{Drug resistance}

A peculiar characteristic of NA use is the possibility of drug resistance. The development of resistance can lead to viral escape, biochemical exacerbation, histological deterioration, hepatic decompensation, and increased risk of hepatic complications. ${ }^{11,25,26}$ Even though rescue treatments are available for resistant cases, good viral suppression is not always attained. ${ }^{27,28}$ In addition to monitor the emergency of resistance, it is also recommended to identify patients with high risk of developing resistance during treatment, and modify the therapeutic regimen as soon as possible.

\section{Different measures of outcomes for treatment with peginterferon and NA}

\section{Sustained response versus maintained response}

PEG-IFN and NA have different mechanisms of action. PEG-IFN has a predominantly immunomodulatory effect and poor antiviral activity. This double action results in the suppression of viral replication and disappearance of infected hepatocytes. NA has a potent antiviral effect through the inhibition of reverse transcriptase activity and HBV-DNA polymerase. ${ }^{29}$ Due to these intrinsic differences between the classes of medications, PEG-INF can be administered for a limited time period, as it presents a more durable response after drug withdrawal. Differently, the NA are usually used for a long time, associated with lower response durability following treatment withdrawal, even after $\mathrm{HBeAg}$ seroconversion or adequate suppression of HBV-DNA. ${ }^{3}$ As a consequence, different time points are used to assess treatment outcome.

Sustained response - defined as persistent therapeutic response for a period after therapy discontinuation - is more appropriate for treatment with PEG-IFN. This period is usually of 6 to 12 months and, sometimes, longer. Maintained response - defined as a response to persistent therapy throughout treatment up to the moment of assessment - is more appropriate for treatment with NA. For maintained response to be significant, it is preferable to count with longer treatment duration, probably for a few years, especially in the case of medications with a low genetic barrier to resistance. If the sustained response for NA is assessed, a longer period of observation after drug withdrawal is necessary, as relapse can occur after the first year postreatment. ${ }^{16}$

\section{Progression markers for PEG-IFN}

The most commonly used marker to assess treatment progression with PEG-IFN is the sustained HBeAg seroconversion, which is usually assessed 6 to 12 months after the end of the treatment. In a long-term follow-up of a European multicentric study, $81 \%$ of the initial respond- 
ers (loss of HBeAg 6 months postreatment) remained HBeAg-negative, whereas $58 \%$ of the initial responders presented levels of HBV-DNA $<2,000 \mathrm{UI} / \mathrm{mL}$, three years after treatment. ${ }^{30}$ Similarly, in a study conducted in Hong Kong, $46 \%$ of the initial responders remained HBeAg-negative and $29 \%$ presented levels of HBV-DNA $<5,000 \mathrm{UI} / \mathrm{mL}$, three years after treatment. ${ }^{15}$

The sustained disappearance of HBsAg is a more complete marker for viral suppression compared to the disappearance of HBeAg. However, $\mathrm{HBsAg}$ clearance is a late event. Studies conducted in Europe and the USA have reported that the late disappearance of HBsAg occurred in $12 \%-65 \%$ of the patients, within five years of HBeAg loss, but it was rarely observed in among Asian patients. ${ }^{8,31-35}$ Among patients who received a one-year treatment with PEG-IFN, 9\%-11\% lost HBsAg three years after the end of treatment. ${ }^{24,30}$ Therefore, predictors for disappearance of HBsAg during treatment are more important than those for seroconversion, but a longer-term follow-up is necessary for their assessment.

\section{Evolution markers for NA}

The maintenance of viral suppression is the most commonly used indicator to measure the effectiveness of NA. As viral resistance can occur if there is persistent active viral replication, undetectable HBV-DNA by polymerase chain reaction (PCR) is required to prevent resistance to NA. In other words, although there is no evidence that suggests that undetectable level of HBV-DNA is necessary for a better prognosis, levels of 2,000 UI/mL can not be used as markers of effectiveness of treatment with NA. As HBsAg disappearance is rarely observed with NA, the assessment of predictors for this outcome can be difficult to achieve and of little use from a clinical point of view. ${ }^{36-41}$

After one year of treatment with NA, the rates of undetectable HBV-DNA by PCR varied from $21 \%-67 \%$ in HBeAg-positive patients and 51\%-90\% in HBeAg-negative patients. ${ }^{29}$ For drugs with low genetic barrier to resistance, new cases of resistance can appear, probably, up to fifth year of treatment. ${ }^{37,42}$ Consequently, predictors of maintained undetectable HBV-DNA levels are more useful if they can predict response at the end of five years. On the other hand, the rate of undetectable HBV increases from $81 \%$ to $87 \%$ when the duration of treatment with entecavir increases from 48 to 144 weeks. ${ }^{39}$ Therefore, predictors of maintained response with HBV-DNA of short-term treatment can be useful for medications with higher genetic barrier to resistance.

\section{Predictors of response to PEG-IFN}

A one-year treatment with PEG-IFN is considered one of the first-choice therapies for chronic hepatitis B. ${ }^{3-5}$ Its main advantage is having a finite treatment period, with absence of viral resistance, which allows other treatment options if there is no initial response. This therapy is better indicated for patients with a high chance of response, as poor responders could be identified and treatment with PEG-IFN should not be offered, or, in the absence of response throughout the treatment, the latter could be discontinued early. According to the experience with chronic hepatitis $C$, the combination of pretreatment and on-treatment factors that predict a favorable response may allow the proposal of an individualized algorithm..$^{43}$

\section{Pretreatment predictors of response to PEG-IFN}

There is a lower possibility for Asian patients to present HBeAg seroconversion in comparison to Caucasians, after receiving interferon. ${ }^{5}$ This observation is partially related to the duration of infection and to HBV genotype. In general, Asians acquire the infection in childhood and present a long phase of immune tolerance, which can cause less effective immunomodulation by treatment with interferon. ${ }^{44}$ The HBV genotype A, prevalent in Western Europe and America, is also associated with higher rates of response to treatment with interferon. ${ }^{45-47}$ In Asia and the Pacific regions, genotypes $\mathrm{B}$ and $\mathrm{C}$ are more prevalent and there is a controversy whether there is any difference regarding their response to interferon. ${ }^{15,45,46}$

Based on the results of well-designed studies, patients with good immunoreactivity tend to respond better to interferon. Immunoreactivity is represented by high levels of ALT, low levels of HBV-DNA and high necroinflammatory activity at histological analysis. High pretreatment ALT levels and low HBV-DNA levels are associated with higher rates of seroconversion with interferon treatment ${ }^{45,46,48,49}$ and also associated with responses to PEG-IFN alpha-2a in HBeAg-negative patients; ALT > 5 - fold the upper limit of normality (ULN) was the most important predictor of combined response (ALT normalization, HBV-DNA suppression) in week 24 postreatment. ${ }^{50}$ Quantitative HBsAg has recently become an important area of scientific interest. Many studies have suggested a correlation between HBsAg titer and the level of covalently closed circular DNA (cccDNA) and total intra-hepatic HBV-DNA. ${ }^{51,55}$ In a pilot-study conducted with three arms, using three different regimens of PEG-IFN and lamivudine, in combination, patients with lower amounts of pre-treatment cccDNA presented higher sustained viral response (SVR). ${ }^{51,52}$ This observation seems logical, as lower levels of cccDNA must result in a stronger immune response. Additionally, quantitative HBsAg, which has moderate correlation with the cccDNA, might provide a reasonable prediction of SVR at a level $<1,000 \mathrm{UI} / \mathrm{mL} .^{51}$ In a smaller study, conducted 
in the Netherlands, pre-treatment HBsAg $\leq 2.25 \log \mathrm{UI} / \mathrm{mL}$ turned out to be a predictor of HBsAg disappearance in patients receiving 48 weeks of PEG-IFN alpha-2a in combination with adefovir. ${ }^{53}$ However, in a large multinational multicentric study, the levels of HBsAg were not good predictors for seroconversion of HBeAg on the sixth and twelfth months after the end of the treatment (Table 1). ${ }^{54}$

Table 1. Predictors of response to PEG-IFN reported in the medical literature. Recommendations based on small observational studies are cited between parenthesis; the other recommendations are based on the analysis of data derived from randomized and controlled studies

\begin{tabular}{ll}
\hline Characteristic & References \\
\hline $\begin{array}{l}\text { Ethnicity } \\
\text { Caucasians }\end{array}$ & 5,44 \\
\hline $\begin{array}{l}\text { HBV Genotype } \\
\text { A }\end{array}$ & $45-47$ \\
\hline $\begin{array}{l}\text { Level of ALT } \\
\text { High }\end{array}$ \\
\hline $\begin{array}{l}\text { HBV-DNA } \\
\text { Lower } \\
\text { Level of HBsAg } \\
\text { Lower }\end{array}$ \\
\hline
\end{tabular}

\section{Response predictors during treatment with PEG-IFN}

\section{Serum HBV-DNA}

The response predictors during treatment with PEG-IFN must be analyzed depending on $\mathrm{HBeAg}$ result. In $\mathrm{HBeAg}$ positive patients treated with conventional interferon, the decrease in HBV-DNA during treatment was associated with an improvement in clinical outcomes. ${ }^{8,65,66}$ Currently, there is no consensus on the best moment and the best HBV-DNA cutoff to predict the response to treatment with PEG-IFN. In an European multicentric study, a decrease of $1 \log (10$-fold) in the levels of serum HBV-DNA in week 32 was a predictor of loss of HBeAg in patients treated with PEG-IFN alpha-2b, receiving monotherapy or a combined therapy with lamivudine. ${ }^{63}$ In a multicentric, randomized, international controlled study, involving $\mathrm{HBeAg}$-negative patients treated with PEG-IFN alpha-2a, $64 \%$ of the patients that attained a decrease in the HBV-DNA of $<400$ copies/mL in week
12 presented a combined sustained response (normal ALT -HBV-DNA $<20,000$ copies/mL) in week 24 posttreatment. ${ }^{57}$ Similarly, in another study with PEG-IFN alpha-2a, which included 40 patients that were previously non-responders to antiviral agents, $64 \%$ of those who attained HBV-DNA $<1,000$ copies/mL in week 24 presented SVR58. However, only a minority of patients can attain a good early control of viremia and a negative predictive value in week 12 or 24 of HBV-DNA for SVR was, approximately, of $70 \% .{ }^{57,58}$ Another limitation to the use of HBV-DNA to predict the response to treatment is its failure to differentiate sustained responders from relapsers. In a French study of $48 \mathrm{HBeAg-negative} \mathrm{patients}$ that received PEG-IFN alpha-2a due to chronic hepatitis $B$, the initial viral kinetics during the treatment of patients that presented viral suppression during therapy, but subsequently presented relapse after the end of the treatment, was almost identical to those with SVR. ${ }^{62}$

One way to use the serum HBV-DNA as a predictor of response during treatment is to establish a withdrawal rule. In a combined post hoc analysis of two clinical trials using a combination of PEG-IFN alpha-2b and lamivudine in $\mathrm{HBeAg}$-positive patients with chronic hepatitis $\mathrm{B},{ }^{52,59}$ failure to decrease HBV-DNA to 10,000 copies $/ \mathrm{mL}$ as early as in week 8 has a negative predictive value of $92 \%$ for SVR. ${ }^{60}$ Based on the data of a randomized international study using PEG-IFN alpha-2a as monotherapy, a much higher cutoff, of $9 \log$ copies/mL in week 24 , was described as presenting a negative predictive value of $86 \%$ for sustained seroconversion of HBeAg. ${ }^{61}$ Whether or not the difference between these two studies is related to the nature of the two PEG-IFN requires further investigation. However, early kinetics of HBV-DNA can help the clinical decision-making of therapeutic withdrawal, particularly among patients that do not present good tolerance to the treatment.

\section{Quantitative HBsAg}

Many studies have shown that the elimination of the cccDNA and levels of HBsAg are associated with SVR during treatment with PEG-IFN.

In a post hoc analysis of 47 patients after antiviral treatment, a lower level of cccDNA at the end of the treatment was associated with higher levels of SVR. ${ }^{59,67}$ In $26 \mathrm{HBeAg}$-positive patients that completed the combined treatment of PEG-IFN alpha-2b for 32 weeks and lamivudine for two years, a level of HBsAg $<1,500 \mathrm{UI} /$ $\mathrm{mL}$ presents $71 \%$ sensitivity and $84 \%$ specificity to predict SVR. ${ }^{51}$ In an international study with PEG-IFN alpha-2a, in HBeAg patients, a level $<10 \mathrm{UI} / \mathrm{mL}$ in week 48 and decline during the treatment $>1 \log \mathrm{UI} / \mathrm{mL}$ can predict a sustained disappearance of $\mathrm{HBsAg}$ three years 
after the use of PEG-IFN alpha-2a, with or without the concomitant use of lamivudine. ${ }^{63}$ As serum levels of HBsAg can be correlated with cccDNA levels, monitoring them has become a reasonable tool to predict the response to treatment with PEG-IFN during its course. In an international study with PEG-IFN alpha-2a in $\mathrm{HBeAg}$-positive patients, a decrease in HBsAg levels $<1,500 \mathrm{UI} / \mathrm{mL}$ in week 12 or 24 might predict an increase in the seroconversion rate of $\mathrm{HBeAg}$ (around $50 \%) .{ }^{54}$ Similarly, $35 \%$ of the HBeAg-negative patients that attained levels of HBsAg of 1,500 UI/mL or less, in week 12 of treatment with PEG-IFN, presented elimination of the HBsAg four years later, after PEG-IFN alpha2 a with or without lamivudine. ${ }^{64}$ Recently, there has been some controversy whether the absolute level of the HBsAg levels, or their decrease during treatment, are the best predictors of response in $\mathrm{HBeAg}$-negative patients. In a French study by Moucari et al ${ }^{62}$ it was verified that a decrease in serum HBsAg $\geq 1 \log \mathrm{UI} / \mathrm{mL}$ in week 12 was described as having a negative predictive value of 97\% for SVR after a 48-week treatment with PEG-IFN alpha-2a (serum HBV-DNA below detection 24 weeks postreatment, see Table 2).

Table 2. Predictors of response during treatment with PEG-IFN reported in the medical literature. Recommendations based on small observational studies are cited between parenthesis; the other recommendations are based on the analysis of data derived from randomized and controlled studies

\begin{tabular}{|c|c|}
\hline Characteristic & References \\
\hline \multicolumn{2}{|l|}{ Level of HBV-DNA } \\
\hline Good response & $52,56-59$ \\
\hline \multicolumn{2}{|l|}{$\begin{array}{l}\text { Week 12: < } 400 \text { copies/mL } \\
\text { (Week 24: < 1,000 copies/mL) }\end{array}$} \\
\hline \multicolumn{2}{|l|}{ Week $32: \geq 1$ log decrease } \\
\hline Poor response & 60,61 \\
\hline \multicolumn{2}{|l|}{ (Week 8: > 10,000 copies/mL) } \\
\hline \multicolumn{2}{|l|}{ Level of HBsAg } \\
\hline Positive HBeAg & $51,54,62-64$ \\
\hline \multicolumn{2}{|l|}{ Weeks 12 and 24: < 1,500 UI/mL } \\
\hline \multicolumn{2}{|l|}{ Negative HBeAg } \\
\hline \multicolumn{2}{|l|}{ Week 12: < 1,500 UI/mL } \\
\hline \multicolumn{2}{|l|}{ Week 24: > 1 log of reduction } \\
\hline Week 48: < $10 \mathrm{UI} / \mathrm{mL}$ & \\
\hline
\end{tabular}

\section{Quantitative $\mathrm{HBeAg}$}

The quantification of HBeAg levels during treatment provides additional information to predict the chance of $\mathrm{HBeAg}$ seroconversion while on treatment with PEG-IFN alpha-2a. In an international study, among $271 \mathrm{HBeAg}$-positive patients treated with PEG-IFN alpha-2a as monotherapy high levels of HBeAg (> 100 Paul Ehrlich Institute Unit/mL) had a higher negative predictive value $(96 \%)$ as compared to serum levels of HBV-DNA (86\%). ${ }^{60}$ Therefore, high levels of HBeAg might be another criterion to predict non-responders. Unfortunately, the quantification of HBeAg titers is yet to be standardized, which prevents its use in clinical practice. Moreover, this evaluation cannot be applied to HBsAg-positive patients.

\section{CONCLUSIONS}

The prediction of the response to the treatment of chronic hepatitis B has become progressively more important as a factor of therapeutic individualization. Pretreatment predictors can help physicians selecting the best moment to initiate treatment, as well as the type of medication to be administered. The predictors of response used during treatment, such as HBV-DNA and quantitative HBsAg, can potentially guide the duration of treatment with PEG-IFN, as it is the case for the treatment of chronic hepatitis $\mathrm{C}$. The use of PEG-IFN has the advantage of the limited time of treatment and the absence of viral resistance, which allows the use of other antiviral agents in early non-responders. The correct use of these predictors may improve response and promote better clinical outcomes of treated chronic hepatitis B patients.

\section{REFERENCES}

1. Chan HLY, Sung JJY. Hepatocellular carcinoma and hepatitis B virus. Semin Liver Dis 2006; 26:153-61.

2. Keeffe EB, Zeuzem S, Koff RS et al. Report of an international workshop: roadmap for management of patients receiving oral therapy for chronic hepatitis B. Clin Gastroenterol Hepatol 2007; 5:890-7.

3. Lok AS, McMahon BJ. Chronic hepatitis B. Hepatology 2007; 45:507-39.

4. European Association for the Study of the Liver. EASL Clinical practice guidelines: management of chronic hepatitis $\mathrm{B}$. J Hepatol 2009; 50:227-42.

5. Liaw YF, Leung NW, Kao JH et al. Asian-Pacific consensus statement on the management of chronic hepatitis B: a 2008 update. Hepatol Int 2008; 2:263-83.

6. Yuen MF, Wong DK, FungJ et al. HBsAg seroclearance in chronic hepatitis B in Asian patients: replicative level and risk of hepatocellular carcinoma. Gastroenterology 2008; 135:1192-9.

7. Lutgehetmann M, Volzt T, Quaas A et al. Sequential combination therapy leads to biochemical and histological improvement despite low ongoing intrahepatic hepatitis B virus replication. Antivir Ther 2008; 13:57-66. 
8. Niederau C, Heintges T, Lange S et al. Long-term follow-up of HBeAg-positive patients treated with interferon alpha for chronic hepatitis B. N Engl J Med 1996; 334:1422-7.

9. de Jongh FE, Janssen HL, de Man RA et al. Survival and prognostic indicators in hepatitis B surface antigen positive cirrhosis of the liver. Gastroenterology 1992; 103:1630-5.

10. Lau DT, Everhart J, Kleiner DE et al. Long-term follow-up of patients with chronic hepatitis B treated with interferon alpha. Gastroenterology 1997; 113:1660-7.

11. Liaw YF, Sung JJ, Chow WC et al. Lamivudine for patients with chronic hepatitis B and advanced liver disease. N Engl J Med 2004; 351:1521-31.

12. Lok AS, Lai CL, Wu PC et al. Spontaneous hepatitis B e antigen to antibody seroconversion and reversion in Chinese patients with chronic hepatitis B virus infection. Gastroenterology 1987; 92:1839-43.

13. Lok AS, Lai CL. Acute exacerbations in Chinese patients with chronic hepatitis B virus (HBV) infection: incidence, predisposing factors and etiology. J Hepatol 1990; 10:29-34.

14. Hsu YS, Chien RN, Yeh CT et al. Long-term outcome after spontaneous HBeAg seroconversion in patients with chronic hepatitis B. Hepatology 2002; 35:1522-7.

15. Chan HLY, Hui AY, Wong VWS et al. Long-term follow up of peginterferon and lamivudine combination treatment in HBeAg-positive chronic hepatitis B. Hepatology 2005; 41:1357-64.

16. van Nunen AB, Hansen BE, Suh DJ et al. Durability of HBeAg seroconversion following antiviral therapy for chronic hepatitis B: relation to type of therapy and pretreatment serum hepatitis B virus DNA and alanine aminotransferase. Gut 2003; 52:420-4.

17. Chen CJ, Yang HI, Su J et al. Risk of hepatocellular carcinoma across a biological gradient of serum hepatitis B virus DNA level. JAMA 2006; 295:65-73.

18. Chan HLY, Tse CH, Mo F et al. High viral load and hepatitis $\mathrm{B}$ virus subgenotype $\mathrm{Ce}$ are associated with increased risk of hepatocellular carcinoma. J Clin Oncol 2008; 26:177-82.

19. Papatheodoridis GV, Dimou E, Dimakopoulos K et al. Outcome of hepatitis B e antigen-negative chronic hepatitis B on long-term nucleos(t)ide analog therapy starting with lamivudine. Hepatology 2005; 42:121-9.

20. Di Marco V, Marzano A, Lampertico P et al. Clinical outcome of $\mathrm{HBeAg}$-negative chronic hepatitis $\mathrm{B}$ in relation to virological response to lamivudine. Hepatology 2004; 40:883-91.

21. Sung JJY, Tsoi KKF, Wong VWS et al. Meta-analysis: Treatment of hepatitis B infection reduces risk of hepatocellular carcinoma. Aliment Pharmacol Ther 2008; 28:1067-77.

22. Wong VWS, Wong GLH, Chim AML et al. Surrogate endpoints and long-term outcome in patients with chronic hepatitis B. Clin Gastroenterol Hepatol 2009 [Epub ahead of publ].

23. Hadziyannis SJ, Tassopoulos NC, Heathcote EJ et al. Long-term therapy with adefovir dipivoxil for $\mathrm{HBeAg}$ negative chronic hepatitis B. N Engl J Med 2005; 352:2673-81.

24. Marcellin P, Bonino F, Lau GK et al. Sustained response of hepatitis $B$ e antigen-negative patients 3 years after treatment with peginterferon alpha-2a. Gastroenterology 2009; 136:2169-79.

25. Lok AS, Lai CL, Leung $\mathrm{N}$ et al. Long- term safety of lamivudine treatment in patients with chronic hepatitis B. Gastroenterology 2003; 125:1714-22.

26. Dienstag JL, Cianciara J, Karayalcin S et al. Durability of serologie response after lamivudine treatment of chronic hepatitis B. Hepatology 2003; 37:748-55.
27. Chan HLY, Wong VWS, Tse CH et al. Early virological suppression is associated with good maintained response to adefovir dipivoxil in lamivudine resistant chronic hepatitis B. Aliment Pharmacol Ther 2007; 25:891-8.

28. Lampertico P, Vigano M, Manenti E et al. Low resistance to adefovir combined with lamivudine: a 3-year study of 145 lamivudine-resistant hepatitis B patients. Gastroenterology 2007; 133:1445-51.

29. Min AD, Dienstag JL. Oral antivirals for chronic hepatitis B. Clin Liver Dis 2007; 11:851-68.

30. Buster EH, Flink HJ, Cakaloglu Y et al. Sustained HbeAg and HBsAg loss after long-term follow-up of HBeAg-positive patients treated with peginterferon alpha-2b. Gastroenterology 2008; 135:459-67.

31. Fattovich G, Giustina G, Realdi G et al. Long-term outcome of hepatitis $\mathrm{B}$ e antigen-positive patients with compensated cirrhosis treated with interferon alpha. European Concerted Action on Viral Hepatitis (EUROHEP). Hepatology 1997; 26:1338-42.

32. Lin SM, Sheen IS, Chien RN et al. Long-term beneficial effect of interferon therapy in patients with chronic hepatitis B virus infection. Hepatology 1999; 29:971-5.

33. Lok AS, Chung HT, Liu VW et al. Long-term follow-up of chronic hepatitis B patients treated with interferon alpha. Gastroenterology 1993; 105:1833-8.

34. Korenman J, Baker B, Waggoner J et al. Long-term remission of chronic hepatitis B after alpha interferon therapy. Ann Intern Med 1991; 114:629-34.

35. Moucari R, Korevaar A, Lada $\mathrm{O}$ et al. High rates of HBsAg seroconversion in $\mathrm{HBeAg}$-positive chronic hepatitis $\mathrm{B}$ patients responding to interferon: a long-term follow-up study. J Hepatol 2009; 50:1084-92.

36. Chang TT, Lai CL, Chien RN et al. Four years of lamivudine treatment in Chinese patients with chronic hepatitis B. J Gastroenterol Hepatol 2004; 19:1276-82.

37. Hadziyannis SJ, Tassopoulos NC, Heathcote EJ et al. Long-term therapy with adefovir dipivoxil for HBeAg-negative chronic hepatitis B for up to 5 years. Gastroenterology 2006; 131:1743-51.

38. Gish R, Chang TT, de Man R et al. Entecavir results in substantial virologic and biochemical improvement and $\mathrm{HBeAg}$ seroconversion through 96 weeks of treatment in $\mathrm{HBeAg}(+)$ Chronic hepatitis B patients (Study ETV-022) [Abstract]. Hepatology 2005; 42(Suppl):267A.

39. Chang TT, Chao YC, Kaymakoglu S et al. Entecavir maintained virologic suppression through 3 years of treatment in antiviral-naive $\mathrm{HBeAg}(+)$ patients (ETV 022/901) [abstract] Hepatology 2006; 44:229A.

40. Lai CL, Gane E, Hsu C-W et al. Two-year results from the GLOBE trial in patients with hepatitis B: greater clinical and antiviral efficacy for telbivudine (LdT) vs. lamivudine [abstract]. Hepatology 2006; 44:222A.

41. Younossi ZM, Benhamou Y, Gane EJ et al. Lack of influence of baseline genotype on antiviral response in subjects with chronic hepatitis B infection receiving tenofovir DF $300 \mathrm{mg}$ QD for 1 year [abstract]. Gastroenterology 2008; 134(Suppl 1):8O9A.

42. Lai CL, Dienstag J, Schiff E et al. Prevalence and clinical correlates of YMDD variants during lamivudine therapy for patients with chronic hepatitis B. Clin Infect Dis 2003; 36:687-96.

43. Ghany MG, Strader DB, Thomas DL et al. Diagnosis, management, and treatment of hepatitis C: an update. Hepatology 2009; 49:1335-74. 
44. Chan HLY, Wong GLH, Wong VWS. A review of the natural history of chronic hepatitis B in the era of transient elastography. Antivir Ther 2009; 14:489-99.

45. Lau GK, Piratvisuth T, Luo KX et al. Peginterferon alpha-2a, lamivudine and the combination for $\mathrm{HBeAg}$-positive chronic hepatitis B. N Engl J Med 2005; 352:2682-95.

46. Janssen HL, van Zonneveld M, Senturk $\mathrm{H}$ et al. Pegylated interferon alpha-2b alone or in combination with lamivudine for HBeAg-positive chronic hepatitis B: a randomised trial. Lancet 2005; 365:123-9.

47. Erhardt A, Blondin D, Hauck K et al. Response to interferon alpha is hepatitis B virus genotype dependent: genotype A is more sensitive to interferon than genotype D. Gut 2005; 54:1009-13.

48. Lok AS, Wu PC, Lai CL et al. A controlled trial of interferon with or without prednisone priming for chronic hepatitis B. Gastroenterology 1992; 102:2091-7.

49. Perrillo RP, Schiff ER, Davis GL et al. A randomized, controlled trial of interferon alpha-2b alone and after prednisone withdrawal for the treatment of chronic hepatitis B. The Hepatitis Interventional Therapy Group. N Engl J Med 1990; 323:295301.

50. Bonino F, Marcellin P, Lau GK et al. Predicting response to peginterferon alpha-2a, lamivudine and the two combined for HBcAg-negative chronic hepatitis B. Gut 2007; 56:699-705.

51. Chan HLY, Wong VWS, Tse AM et al. Serum hepatitis B surface antigen quantitation can reflect hepatitis $B$ virus in the liver and predict treatment response. Clin Gastroenterol Hepatol 2007; 5:1462-8.

52. Chan HLY, Wong VWS, Chim AML et al. Virological response to different combination regimens of peginterferon alpha- $2 \mathrm{~b}$ and lamivudine in hepatitis $\mathrm{B}$ e antigen positive chronic hepatitis B. Antivir Ther 2007; 12:815-23.

53. Takkenberg B, Zaaijer H, Weegink C et al. Baseline HbsAg level predict HBsAg loss in chronic hepatitis B patients treated with a combination of peginterferon alpha-2a and adefovir: an interim analysis. J Hepatol 2009; 50(Suppl 1):S8.

54. Lau GK, Marcellin P, Brunetto M et al. On-treatment HBsAg decline during peginterferon alpha-2a $(40 \mathrm{KD})+/$ - lamivudine in patients with $\mathrm{HBeAg}$-positive $\mathrm{CHB}$ as a potential predictor of durable off-treatment response [abstract]. Hepatology 2008; 48(Suppl 1):714A.

55. Wcrle-Lapostolle B, Bowden S, Locarnini S et al. Persistence of cccDNA during the natural history of chronic hepatitis B and decline during adefovir dipivoxil therapy, Gastroenterology 2004; 126:1750-8.
56. ter Borg MJ, van Zonneveld M, Zeuzem S et al. Patterns of viral decline during peginterferon alpha-2b therapy in $\mathrm{HBeAg}$ positive chronic hepatitis $\mathrm{B}$ : relation to treatment response. Hepatology 2006; 44:721-7.

57. Farci P, Marcellin P, Lu ZM et al. On-treatment predictors of sustained biochemical and virological response in patients with $\mathrm{HBeAg}$-negative chronic hepatitis $\mathrm{B}(\mathrm{CHB})$ treated with peginterferon alpha-2a $(40 \mathrm{kDa})\left(\right.$ Pegasys $\left.^{\circledR}\right)$ [abstract]. J Hepatol 2005; 42(Suppl 2):175A.

58. Chan HLY, Wong VWS, Chim AML et al. Treatment of patients with chronic hepatitis B who have failed previous antiviral treatment with pegylated interferon alpha-2a (40kda; PEGASYS). Antivir Ther 2008; 13:555-62.

59. Chan HLY, Leung NWY, Hui AY et al. A randomized, controlled trial of combination therapy for chronic hepatitis B: comparing pegylated interferon-a2b and lamivudine with lamivudine alone. Ann Intern Med 2005; 142:240-50.

60. Chan HLY, Wong VWS, Wong GLH et al. Early hepatitis B virus DNA suppression can predict virologie response to peginterferon and lamivudine treatment. Clin Gastroenterol Hepatol 2008; 6:1022-6.

61. Fried MW, Piratvisuth T, Lau GK et al. HBeAg and hepatitis B virus DNA as outcome predictors during therapy with peginterferon alpha-2a for HBeAg-positive chronic hepatitis B. Hepatology 2008; 47:428-34.

62. Moucari R, Mackiewicz V, Lada O et al. Early serum HBsAg drop: a strong predictor of sustained virological response to pegylated interferon alpha-2a in HBeAg-negative patients. Hepatology 2009; 49:1151-7.

63. Brunetto MR, Moriconi F, Bonino F et al. Hepatitis B virus surface antigen levels: a guide to sustained response to peginterferon alpha-2a in HBeAg-negative chronic hepatitis B. Hepatology 2009; 49:1141-50.

64. Marcellin P, Brunetto M, Bonino F et al. In patients with HbeAg-negative chronic hepatitis B HBsAg serum levels early during treatment with peginterferon alpha-2a predict $\mathrm{H}$ BsAg clearance 4 years postreatment [abstract]. Hepatology 2008; 48(Suppl 1): 7I8A.

65. Lin SM, Yu ML, Lee CM et al. Interferon therapy in HBeAg positive chronic hepatitis reduces progression to cirrhosis and hepatocellular carcinoma. J Hepatol 2007; 46:45-52.

66. van Zonneveld M, Honkoop P, Hansen BE et al. Long-term follow-up of alphainterferon treatment of patients with chronic hepatitis B. Hepatology 2004; 39:804-10.

67. Sung JJ, Wong ML, Bowden S et al. Intrahepatic hepatitis B virus covalently closed circular DNA can be a predictor of sustained response to therapy. Gastroenterology 2005; 128:1890-7. 